\title{
Audit Committees and COVID-19-Related Disclosure Tone: Evidence from Oman
}

\author{
Badar Alshabibi ${ }^{1, *(\mathbb{D})}$, Shanmuga Pria ${ }^{2}$ and Khaled Hussainey ${ }^{3}$ (D) \\ 1 Faculty of Business Studies, University of Technology and Applied Sciences-Muscat, Al-Khuwair, \\ Muscat 133, Oman \\ 2 Faculty of Business Studies, University of Technology and Applied Sciences-Shinas, Al-Aqur, \\ Shinas 324, Oman \\ 3 Accounting and Financial Management Subject Group, Faculty of Business and Law, \\ University of Portsmouth, Portsmouth PO1 2UP, UK \\ * Correspondence: badar.alshabibi@hct.edu.om
}

Citation: Alshabibi, Badar, Shanmuga Pria, and Khaled Hussainey. 2021. Audit Committees and COVID-19-Related Disclosure Tone: Evidence from Oman. Journal of Risk and Financial Management 14: 609 https://doi.org/10.3390/jrfm14120609

Academic Editors: Jakub Horák and Donald Lien

Received: 7 November 2021

Accepted: 10 December 2021

Published: 15 December 202

Publisher's Note: MDPI stays neutral with regard to jurisdictional claims in published maps and institutional affiliations.

Copyright: (C) 2021 by the authors Licensee MDPI, Basel, Switzerland. This article is an open access article distributed under the terms and conditions of the Creative Commons Attribution (CC BY) license (https:/ / creativecommons.org/licenses/by/ $4.0 /)$.

\begin{abstract}
In this study, we content analyzed chairman's statements to measure the tone of COVID19-related disclosure in Omani listed firms for the year ending 2020. We also examined whether audit committee $(\mathrm{AC})$ characteristics influence disclosure tone. After controlling for corporate board and firm characteristics, our regression analysis showed that two AC characteristics (gender diversity and overlapped directors) positively affect good news information and negatively affect bad news information. It also showed that AC size positively affects bad news information. No evidence was found that the $\mathrm{AC}$ independence, meeting frequency, multi-directorships, and financial expertise have an impact on the tone of COVID-19-related disclosures. Our paper contributes to the growing literature by being the first study to examine whether AC characteristics influenced disclosure tone during the COVID-19 pandemic. Our results indicate that investors and regulatory bodies should take AC characteristics into account in determining the tone of COVID-19-related disclosures.
\end{abstract}

Keywords: COVID-19-related disclosure tone; audit committee; chairman's statement; Sultanate of Oman

\section{Introduction}

As stakeholders' demand for voluntary disclosure is always high, we believe that annual report narratives (e.g., chairman's statements) could be an effective communication channel for companies to disseminate information on how the COVID-19 pandemic affects their current and future performance and the proposed action plan. Such disclosures could reduce information asymmetry and could lead to positive economic consequences.

Corporate voluntary disclosure has received much attention during the COVID-19 pandemic (Elmarzouky et al. 2021). For example, a report introduced by the Financial Reporting Council has highlighted the importance of corporate governance and COVID-19 narrative disclosure during the pandemic. In line with this, Albitar et al. (2021) provide evidence that companies communicate COVID-19-related information in corporate annual reports and governance quality (measured by gender diversity) is one of the contributing factors that affects disclosure levels. In addition, Elmarzouky et al. (2021) examine the relationship between performance narrative disclosure and COVID-19 narrative disclosure in the narrative sections of corporate annual reports and how governance affects this relationship. One of their findings is that governance quality (measured by board independence and gender diversity) moderated the disclosure practice during the COVID-19 pandemic. They call for research that explores the tone of COVID-19 disclosures.

An effective audit committee (AC) plays a major role in corporate governance (Smith 2003) and improves the quality of financial reporting through improving the quality and quantity of voluntary disclosures (Al Lawati et al. 2021). Although considerable 
attention has been paid to examining the impact of governance on disclosure since the publication of a remarkable paper by Eng and Mak (2003), we have not found any studies exploring the extent to which AC characteristics affect COVID-19-related disclosure tone. We focus on ACs in our paper as prior research shows that the characteristics of ACs affect their ability to oversee the corporate financial reporting process and voluntary disclosure practice (Al Lawati and Hussainey 2021; Al Lawati et al. 2021; Al-Shaer et al. 2017; Al-Shaer and Zaman 2018; Ho and Wong 2001).

The contributions of our study are largely empirical. Our paper responds to the recent call by Elmarzouky et al. (2021) and measures the tone of COVID-19-related disclosures. We also complement Elmarzouky et al. (2021)'s study by examining the influence of AC characteristics on COVID-19-related disclosure tone. We also complement a recent study by Salem and Hussainey (2021), who examine the levels of COVID-19 disclosure in two Islamic banks in Oman. We extend their work by exploring the COVID-19-related disclosure tone in all financial and non-financial companies in Oman and then we examine factors affecting disclosure tone.

We focus on the Omani context for a number of reasons. First, Oman was one of the first countries in the Middle East and North Africa region to issue a voluntary corporate governance code (in 2002), which it effectively implemented in 2003. The code was revised in 2016, and one of its pillars is transparency, where the board of directors is required to provide regulators, investors, and related parties with accurate and timely information to enable them to make appropriate decisions (Capital Market Authority (CMA 2016)). The code also emphasizes that the corporate board should adopt the disclosure policy of the company as per the regulatory requirement. Second, the CMA and the Muscat Stock Exchange (MSX) announced the implementation of a new XBRL disclosure platform in August 2020 (XBRL 2020). The platform aims to enhance disclosure quality. These new digital data provided by the new platform are expected to assist investors as well as analysts to make timely and quick investment decisions. Third, the CMA provides for the best ways for investors to access the information they require, which in turn maximizes the confidence of the domestic and foreign investors in the local stock market (CMA 2021). It is believed that increases in such confidence can be attributed to disclosure quality. Our study, therefore, could provide interesting insights to stakeholders into the COVID-19related disclosure tone in Oman and factors affecting this type of disclosure. This may help with initiating certain forms of regulation regarding voluntary disclosure and governance in Oman.

\section{Relevant Literature and Research Hypotheses}

In our paper, we focus on a number of AC characteristics. These include size, independence, the number of meetings, gender diversity, nationality diversity, overlapped directorships, multiple directorships, and accounting/financial expertise.

\subsection{AC Size}

AC directors are responsible for overseeing companies' financial reporting processes (Al Lawati et al. 2021). On the one hand, Ho and Wong (2001) find that the effectiveness of AC directors has a positive impact on voluntary disclosure. Bedard and Johnstone (2004) find that ACs with a large number of directors should have "the necessary strength, diversity of expertise, and viewpoints to provide effective monitoring", which leads to better disclosure. Appuhami and Tashakor (2017) and Raimo et al. (2021) provide evidence that a large AC size has a positive impact on disclosure quality. On the other hand, large committees may suffer from the free-rider problem and dispersed tasks, and this might negatively affect disclosure quality (Li et al. 2012; Mangena and Pike 2005).

\subsection{AC Independence}

Aboody and Lev (2000) and Li et al. (2012) show that the independence of AC directors can: (i) safeguard stakeholders from managers' opportunistic behavior; and (ii) improve 
the efficacy of the monitoring process, thereby improving disclosure quality. The literature on the influence of the independence of AC directors on corporate disclosure offers mixed results. On the one hand, Al-Maghzom et al. (2016) and Li et al. (2012) find that the independence of AC directors does not affect corporate disclosure levels. On the other hand, Xie et al. (2003) find that the independence of AC directors negatively affects the quality of financial reporting (as measured by discretionary accrual). Al-Najjar and Abed (2014) also find that $\mathrm{AC}$ independence affects disclosure levels.

\subsection{AC Meetings}

It is believed in the disclosure and governance literature that the frequency of annual AC meetings improves disclosure quality (Gebrayel et al. 2018). Regular AC meetings allow directors to be informed of (and proactive about) disclosure-related issues. So, AC directors will be more effective in their monitoring role, and this could enhance disclosure quality (Karamanou and Vafeas 2005). This is also supported by Abbott et al. (2004), who argue that AC directors who meet regularly will be able to quickly handle accounting, auditing, and disclosure issues. Prior research provides mixed findings. On the one hand, Raimo et al. (2020) find that AC meetings positively affect disclosure levels. On the other hand, studies find that AC meetings have a negative impact on the quality of financial reports (Sharma and Iselin 2012) or have no impact on voluntary disclosure (Al Lawati and Hussainey 2021).

\subsection{Gender Diversity in ACs}

Gender diversity in the boardroom reflects the fair representation of directors of different genders. On the one hand, Gul et al. (2011) argue that gender diversity in the boardroom enhances the efficiency of AC directors and their capacity to oversee corporate disclosure. Allini et al. (2016) find that female directors positively affect voluntary disclosure. The most related papers to ours are Al Lawati et al. (2021) and Albitar et al. (2021). Al Lawati et al. (2021) find that female AC directors have a positive impact on the disclosure quality in Omani financial institutions. Albitar et al. (2021, p. 419) find that "when firms have more female directors on the board, they would have stronger corporate governance. As a result, the disclosure of COVID-related information is more pronounced". On the other hand, studies have found a negative impact of female directors on voluntary disclosure (Allini et al. 2014).

\subsection{Nationality Diversity in ACs}

The existence of foreign AC directors improves management's oversight and the alignment of interests between owners and managers (Grassa et al. 2020). Foreign directors add to the corporate decision-making process by sharing their understanding of contextual concerns in foreign markets (Zahra and Filatotchev 2004). On the one hand, Barako et al. (2006), Grassa et al. (2020), and Haniffa and Cooke (2002) provide evidence that foreign board members improve corporate disclosure. On the other hand, foreign AC directors might have a negative impact on disclosure levels because of culture issues (e.g., their awareness of the national context is limited) (Al-Matari et al. 2014). Similarly, Cao et al. (2019) argue that communication and collaboration among board members are hampered by national cultural diversity and this could affect disclosure levels.

\subsection{Overlapping AC Membership}

Overlapping AC membership occurs when an AC member serves on other board committees within the same company (Al Lawati and Hussainey 2021; Al Lawati et al. 2021). Based on the agent theory, the existence of overlapping AC members should lead to enhanced board effectiveness (Jensen and Meckling 1976; Ross 1973). On the one hand, the empirical disclosure literature provides evidence that overlapping AC membership has a positive impact on the quality and quantity of disclosures (Al Lawati and Hussainey 2021; Al Lawati et al. 2021; Chandar et al. 2012; Habib and Bhuiyan 2016; Velte 2021). On the 
other hand, based on the busyness or overcommitment hypothesis, other studies find that overlapping directorships negatively affect the quality of financial reporting (Chang et al. 2011; Karim et al. 2016; Sultana et al. 2019).

\subsection{Multiple AC Directorships}

Multiple directorships "refer to the case where a director who is affiliated with one company also sits on the board of directors of other companies" (Smith and Sarabi 2021). AC directors with multiple directorships are perceived to be valuable and important as they aim to maintain their reputation and to fulfill their monitoring role effectively (Fama and Jensen 1983). They are effective in monitoring corporate managers (Shivdasani and Yermack 1999). The literature on the impact of multiple directorships on voluntary disclosure is mixed. On the one hand, Haniffa and Cooke (2005) find that AC directors with multiple directorships positively affect disclosure levels. This suggests that multiple directorships held by ACs in other firms potentially improve their knowledge and experience in improving the quality of disclosure. Al Lawati et al. (2021) find that AC directors with multiple directorships have a positive impact on the disclosure quality in Omani financial institutions. On the other hand, the busyness or overcommitment hypothesis suggests a negative impact of directors with multiple directorships on disclosure. For example, Chang et al. (2011), Karim et al. (2016), and Sultana et al. (2019) provide empirical evidence that the quality of financial reports is reduced when corporate directors are busy with or overcommitted to other directorships.

\subsection{ACs with Financial Expertise}

ACs with financial expertise refer to ACs whose directors have accounting and/or finance backgrounds. These directors are better positioned to comprehend the consequences of voluntary disclosures (Li et al. 2012). Directors with no experience in accounting or finance are less likely to recognize issues related to corporate disclosure practice (Agrawal and Chadha 2005). The literature on the AC financial expertise-disclosure relationship is mixed. On the one hand, Mangena and Pike (2005) provide evidence that ACs with financial expertise have a positive impact on disclosure. On the other hand, Al Lawati and Hussainey (2021), Raimo et al. (2020), and Wang and Hussainey (2013) find that ACs with financial expertise do not influence corporate disclosure.

Following prior studies on disclosure (e.g., Elshandidy et al. 2013), and because of the mixed findings in the governance and disclosure literature, we formulated the following non-directional research hypotheses on the impact of the characteristics of ACs on COVID19-related disclosure tone as follows:

Hypothesis 1 (H1). COVID-19-related disclosure tone is likely to be influenced by AC size.

Hypothesis 2 (H2). COVID-19-related disclosure tone is likely to be influenced by AC independence.

Hypothesis 3 (H3). COVID-19-related disclosure tone is likely to be influenced by AC meetings.

Hypothesis 4 (H4). COVID-19-related disclosure tone is likely to be influenced by AC gender diversity.

Hypothesis 5 (H5). COVID-19-related disclosure tone is likely to be influenced by AC nationality diversity.

Hypothesis 6 (H6). COVID-19-related disclosure tone is likely to be influenced by AC overlap.

Hypothesis 7 (H7). COVID-related disclosure tone is likely to be influenced by AC multiple directorships.

Hypothesis 8 (H8). COVID-related disclosure tone is likely to be influenced by AC financial expertise. 


\section{Method}

\subsection{Sample Selection Criteria}

In this study, we included all listed firms in the Muscat Securities Exchange (MSX) in Oman. We downloaded annual reports from companies' websites. We had a sufficient number of observations for the statistical analysis and our sample was larger than the sample used in related research papers (e.g., Al Lawati et al. 2021). The initial sample consisted of 109 firms listed in the Muscat Securities Market in 2020. The sample was reduced due to a number of observations. We lost eleven companies because the annual reports for these companies were not available. We lost three additional firms due to their liquidation, delisting, or merger with another company during 2020. So, the sample used in our analysis was comprised of 95 firms. We choose the year 2020 as it was the center of the COVID-19 pandemic. The voluntary disclosure information was manually collected from the chairman's reports available in the annual reports for the year ended 2020. Firm-specific characteristics and corporate governance data were collected from corporate annual reports.

\subsection{Variables: Measurement and Description}

\subsubsection{Good News/Bad News Disclosure Measure}

The dependent variables were the number of COVID-19 good news sentences and the number of COVID-19 bad news sentences in the chairman's report. Following prior research (Al Lawati and Hussainey 2021; Al Lawati et al. 2021), sentences were chosen as the text unit for the analysis.

\subsubsection{Explanatory Variables}

We included eight independent variables as follows. AC size (ACSize) was measured by the number of AC directors. Independence of AC directors ( $A C I n d)$ was measured by the proportion of independent $\mathrm{AC}$ directors. $\mathrm{AC}$ meetings (ACMeet) was measured by the number of AC meetings. Gender diversity was measured by the proportion of female AC directors on the board (ACFem). Nationality diversity was measured by the percentage of foreign AC directors on the board (ACNationality). Overlapping AC directors (ACOverlap) were measured by the number of directors who served on the $\mathrm{AC}$ and other committees at the same time for the same company divided by AC size. AC multiple directorships $(A C M u l)$ were measured by the percentage of AC directors serving on multiple boards. The percentage of AC members with financial or accounting expertise (ACFin) was measured, following Al Lawati et al. (2021), as the number of directors who were "certified public accountants (CPAs) or had prior work experience as a chief financial officer (CFO), vice president of finance, financial controller, investment banker, chief investment officer, financial analyst, auditor, or any other corporate finance or major accounting position" (p. 570).

\subsubsection{Control Variables}

Prior research shows that the quality of the board of directors affects financial reporting practices (Abdou et al. 2021; Al-Shaer et al. 2021). We, therefore, included the following characteristics of the board of directors as control variables in our regression model:

- Board size (BSize), measured as the number of directors on the board of firm $i$ in period $t$ (Elshandidy et al. 2013; Larmou and Vafeas 2010; Wang and Hussainey 2013);

- $\quad$ Board independence (BINED), measured as the proportion of independent directors on the board for firm $i$ in period $t$ (Al Lawati et al. 2021; Arcay and Vázquez 2005; Barako et al. 2006; Beasley 1996; Elshandidy et al. 2013; Saha and Kabra 2021);

- Board meetings (BMeeting), measured as the total number of meetings held by the board during the fiscal year for firm $i$ in period $t$ (Al Lawati et al. 2021; Khaireddine et al. 2020);

- Board gender (BGender) diversity, measured as the proportion of female directors across the board for firm $i$ in period $t$ (Nicolo et al. 2021; Saha and Kabra 2021); 
- Board nationality (Bnationality) diversity, measured as the percentage of foreign directors across the board (Ayman et al. 2019; Elgammal et al. 2018; Shehadeh et al. 2021);

- $\quad$ Relative members (Relatives) refer to the existence of directors from the same family in the boardroom. We looked at the surnames of the directors and used a dummy variable equal to 1 if a firm has directors from the same family and 0 otherwise (Al-Hadi et al. 2016; Al Lawati and Hussainey 2021; Boshnak 2021; Eulaiwi et al. 2016; Nindiasari 2021);

- Royal Family (Royal) is a dummy variable equal to 1 if a firm has at least one ruling director on the board and 0 otherwise (Alazzani et al. 2019; Al Lawati and Hussainey 2021).

Following prior research, we also controlled for auditor quality, which was measured by a dummy variable equal to 1 for Big Four audit firms and 0 otherwise (Albitar et al. 2021; Al-Hadi et al. 2016; Mcchlery and Hussainey 2021). We also followed the literature and controlled for firm size, which was measured by the natural log of total assets; leverage (LEV), which was measured by the debt to total assets ratio; and profitability, which was measured by the return on equity (ROE) ratio (Al Lawati and Hussainey 2021; Al-Shaer et al. 2021; Elshandidy et al. 2013; Mcchlery and Hussainey 2021).

\subsection{Content Analysis}

Content analysis was used to identify the disclosure tone (good news information versus bad news information) in the chairman's reports from Omani companies. It is worth noting that that some statements are based on the judgment of the users. It is also possible that these disclosures could be both good and bad at the same time, depending on the user groups. A disclosure may be good for an investor but bad for a customer or vice versa. As the chairman of HSBC Oman stated:

"We have also established relief measures for our retail and wholesale customers who have been impacted by COVID-19, including the deferral of loan instalments and fee waivers." [HSBC Bank Oman, SAOG, (2020) p. 3]

We consider the above statement to be good news information because the bank's clients and customers will be able to manage their payment schemes and avoid defaults and lengthy and costly litigation. However, it could also be categorized as bad news because it could affect the financial position of the bank. Contracted economic activity reduces a company's liquidity position at it may be aggravated due to the deferment of loan repayments and financial losses in terms of the fees waived.

Another example is given by the chairman of Shell Oman Marketing:

"In light of the economic impact of the COVID-19 pandemic and the parallel challenges in the market, the Board of Directors decided to propose to shareholders that no dividends be distributed for the year ended 31 December 2020." [Shell Oman Marketing Company, SAOG, (2020) p. 2]

The above statement, from the perspective of investors, might be bad news due to the non-distribution of dividends; however, it will be good news for the company itself as it might indicate that more liquid assets will be available to meet any future liabilities.

In Table 1, the dimensions of the manual content analysis are classified. For market conditions and expectations, the chairman of Al Batinah Development and Investment Holding Company stated that:

"Expectations have indicated that the year 2021 AD will be a full year of challenges and difficulties due to the continuing outbreak of the coronavirus pandemic and perhaps the return of closures to some regions and commercial activities, the instability of oil prices, precautionary measures for travel and tourism, and a weak investor appetite for investments in the financial market and real estate investment sector but optimism remains present and strengthened." [Al Batinah Development and Investment Holding Company, SAOG, (2020) p. 3] 
Table 1. Dimensions of COVID-19 information.

\begin{tabular}{|c|c|c|}
\hline $\begin{array}{c}\text { Dimension of } \\
\text { COVID-19 Disclosure }\end{array}$ & Examples of Good News Themes & Examples of Bad News Themes \\
\hline $\begin{array}{l}\text { Impact of the } \\
\text { pandemic }\end{array}$ & $\begin{array}{l}\text { - } \quad \text { Economic program shift } \\
\text { Economic recovery and revival of equity } \\
\text { market }\end{array}$ & $\begin{array}{l}\text { - } \quad \text { Adverse impact on the global, regional, and local economy } \\
\text { - } \quad \text { Pestrictions on business activities } \\
\text { - } \quad \text { Severe disruption in the supply of goods, materials, and people } \\
\text { - } \quad \text { Severe contraction of economic activities } \\
\text { - } \quad \text { Impact on local ond foreign markets } \\
\text { - Interruptions in achieving strategic goals } \\
\text { - } \quad \text { Adverse impact on company's performance } \\
\text { Outbreaks in labor camps }\end{array}$ \\
\hline $\begin{array}{l}\text { Market condition and } \\
\text { expectations }\end{array}$ & $\begin{array}{ll}\text { - } & \text { Positive economic outlook } \\
\text { - } & \text { Company's resiliency } \\
\text { - } & \text { Business optimism } \\
\text { - } & \text { Positive regional and local outlook } \\
\text { - } & \text { Government regulatory intervention } \\
\text { - } & \text { Positive market opportunity }\end{array}$ & $\begin{array}{ll}- & \text { Depressed global, regional, and local economic conditions } \\
\text { - } & \text { Slow economic recovery } \\
\text { - } & \text { Economic uncertainties } \\
\text { - } & \text { Dependency on mitigation measures } \\
\text { - } & \text { Gloomy economic outlook }\end{array}$ \\
\hline Growth & $\begin{array}{ll}- & \text { Steady and strong performance } \\
\text { - } & \text { Increased/strong demand and } \\
\text { production }\end{array}$ & $\begin{array}{ll}- & \text { Decrease in demand and production } \\
- & \text { Less planned growth } \\
\text { - } & \text { Idle resources and overruns } \\
\text { - } & \text { Export market lockdowns } \\
\text { - } & \text { Decrease in market performance } \\
\text { - } & \text { Delay in company/subsidiary production } \\
& \text { Decline orket constraints }\end{array}$ \\
\hline $\begin{array}{l}\text { Profitability and } \\
\text { financial position }\end{array}$ & $\begin{array}{ll}- & \text { Increased profitability of } \\
& \text { company/subsidiary } \\
- & \text { Exceeded financial goal } \\
- & \text { Decreased/controlled costs } \\
- & \text { Growth in key financial metrics } \\
\text { - } & \text { Robust liquidity position }\end{array}$ & $\begin{array}{ll}\text { - } & \text { Decreased profitability/unmet profit objectives of } \\
& \text { company/subsidiary } \\
\text { - } & \text { Increased losses } \\
\text { - } & \text { Decline in sales and sales volume } \\
\text { - } & \text { Increased sales pressures } \\
\text { - } \quad \text { Government-mandated payment of claims } \\
\text { - Increased provision for expected losses } \\
\text { Softening of rates }\end{array}$ \\
\hline Operations & $\begin{array}{ll}\text { - } & \text { Reliable plant operations } \\
\text { Excellent operational support and } \\
\text { maintenance team } \\
\text { - } \quad \text { Health and safety environment } \\
\text { Excellent operational performance }\end{array}$ & $\begin{array}{ll}-\quad \text { Disrupted operations } \\
-\quad \text { Temporary suspension of operations } \\
-\quad \text { Longer shifts }\end{array}$ \\
\hline Social responsibility & $\begin{array}{l}\text { - } \quad \text { Donations to the Ministry of } \\
\text { Health/community to fight COVID-19 } \\
\text { Established a Polymerase Chain Reaction } \\
\text { (PCR) testing facility } \\
\text { - Increased the health and safety } \\
\text { awareness of the general public } \\
\text { - Donations to the Ministry of Education } \\
\text { Deferral of the payment of loans } \\
\text { Disbursement for relief and recovery }\end{array}$ & $\begin{array}{ll}- & \text { Reduced CSR activities } \\
- & \text { Suspended CSR activities }\end{array}$ \\
\hline Strategic disclosure & 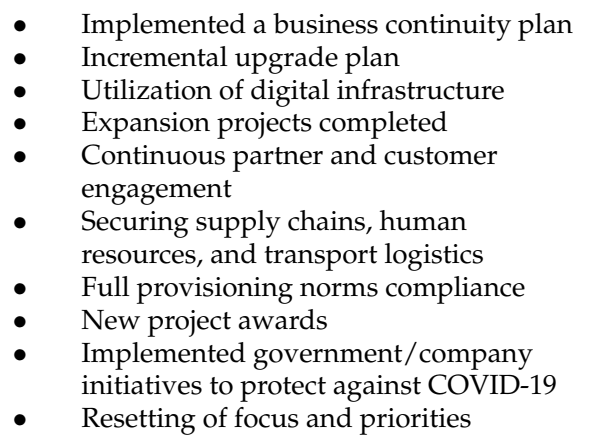 & $\begin{array}{l}\text { - } \quad \text { Slow operation of new project acquisition } \\
\text { - } \quad \text { Delay in business transformation } \\
\text { - } \quad \text { Delay in investment project implementation } \\
\text { - } \quad \text { Dostponement of dividend distribution to stockholders. } \\
\text { - }\end{array}$ \\
\hline
\end{tabular}

The table was prepared by the authors after reading the chairman's statements of the sampled companies. It shows examples of the main themes of COVID-related disclosure tone in Omani listed firms. 
In another statement, Sahara Hospitality's chairman emphasizes the impact of the pandemic:

"The COVID-19 pandemic situation has caused an adverse impact on our business during the year ended 30th November 2020 with reported reduced occupancy levels since March 2020." [Sahara Hospitality Co, SAOG (2020), p. 1]

The following examples of chairman's statements discuss issues related to operations, social responsibilities, growth, profitability, and strategic disclosures:

"As per the guidelines issued by the Supreme Committee dealing with COVID-19 in the Sultanate of Oman, all entities (other than those dealing with essential services) had to temporarily suspend their operations from 23 March 2020 as part of the precautionary measures aimed to limit the spread of COVID-19 in the Sultanate of Oman." [UBAR Hotel and Resorts, SAOG, (2020), p. 1]

"This year, however, due to the COVID-19 pandemic, most of our programs originally planned as a part of our CSR have been suspended to minimize physical contacts, which has been essential to prevent the spread of COVID-19." [Muscat City Desalination Company, SAOG, (2020), p. 1]

"COVID-19 and the oil price crisis both had a direct negative impact on performance in 2020. Higher costs, lower occupancy, and reduced activity all affected revenue and profit." [Renaissance Services, SAOG, (2020), p. 2]

"As a direct consequence of the pandemic, the construction industry in GCC as per Deloitte went through a very difficult period post Q1-2020, with over USD 60 billion worth of projects being put on hold or being cancelled leading to a big demand pull back for steel." [Al Jazeera Products Co. SAOG, (2020), p. 1]

In the content analysis method, one of the essential considerations is its reliability. Stability and reproducibility are used in the literature as measures for reliability (Krippendorff 2004). Stability is achieved when the same chairman's statements are coded more than once by the same researcher. Therefore, the statement of the chairman of UBAR Hotel and Resorts, SAOG was coded and recoded by one of the authors of this paper and the results show stability. Reproducibility is also confirmed where the chairman's statement has been coded and recoded by more than one researcher. Statements were randomly selected and then independently coded by two authors of this paper, and the correlation between their disclosure scores was above $90 \%$ and statistically significant. Cronbach's Alpha is also used to measure the validity of scores and our analysis shows that the Cronbach's alpha coefficient of internal consistency is 0.94 (compared with 0.70 in the disclosure literature). Based on this, we conclude that our disclosure measure is reliable and valid.

\subsection{Regression Models}

An ordinary least squares (OLS) regression model was used in this study to test our research hypotheses as follows:

Good News $\%=\alpha 0+\beta 1$ ACSize $+\beta 2$ ACINED $+\beta 3$ ACMeeting $+\beta 4$ ACGender $+\beta 5$ ACNationality + $\beta 6$ ACOverlap $+\beta 7$ ACMul $+\beta 8$ ACFIN $+\beta 9$ BSize $+\beta 10$ BINED $+\beta 11$ BMeeting $+\beta 12$ BGender $+\beta 13$ BNationality $+\beta 14$ Royal $+\beta 15$ Relatives $+\beta 16$ Big $4+\beta 17$ Log Total Asset $+\beta 18$ LEV $+\beta 19$ ROE $+\varepsilon$

Bad News $\%=\alpha 0+\beta 1$ ACSize $+\beta 2$ ACINED $+\beta 3$ ACMeeting $+\beta 4$ ACGender $+\beta 5$ ACNationality + $\beta 6$ ACOverlap $+\beta 7$ ACMul $+\beta 8$ ACFIN $+\beta 9$ BSize $+\beta 10$ BINED $+\beta 11$ BMeeting $+\beta 12$ BGender $+\beta 13$ BNationality $+\beta 14$ Royal $+\beta 15$ Relatives $+\beta 16$ Big $4+\beta 17$ Log Total Asset $+\beta 18$ LEV $+\beta 19$ ROE $+\varepsilon$

\section{Our Findings}

\subsection{Descriptive Analysis}

Our descriptive analysis (not tabulated for brevity) produced interesting findings. On average, a total of $29 \%$ of the chairman's reports contain good news information, while 
$58 \%$ contain bad news information. The mean AC size is 3.3 (maximum = five directors; minimum $=$ two directors). A total of $75 \%$ of the AC directors are independent. The average number of AC meetings is about 5 meetings per year (maximum $=16$ meetings; minimum $=2$ meetings). The proportion of AC directors with financial expertise is $80 \%$. The average values for overlapping AC directors and multiple directorships are 25 percent and 64 percent, respectively.

The average board size is 7 (a maximum of 11 directors). The average level of board independence is 61 percent. On average, board members meet seven times a year. The average gender diversity is $4 \%$. The average nationality diversity is $33 \%$. A total of $41 \%$ of our sampled companies are audited by Big Four auditing firms. On average, a total of $14 \%$ of the directors in the boardroom are royal members and $19 \%$ have a relative in the boardroom. The average ROE is $8 \%$.

\subsection{Correlation Analysis}

In our analysis (not tabulated for brevity), the correlation between Bsize and Big4 is positive and statistically significant at the $1 \%$ level. We found positive relations between BMeeting, BGender, BNationality, ACSize, ACMeeting, ACGender, ACNationality, ACOverlap, ACFIN, Royal, and ROE. We found negative relationships between BINED, ACINED, and ACmul. There is also a positive correlation between total assets and leverage. The correlation between the independent variables is less than $70 \%$, so the multicollinearity problem does not exist.

\subsection{Empirical Findings}

Table 2 shows our empirical findings. In Model (1), we tested to see whether AC characteristics affect the positive information related to COVID-19, while in Model (2), we tested to see the impact of AC characteristics on the negative information related to COVID-19.

Table 2. Multiple Regression Analysis.

\begin{tabular}{|c|c|c|c|c|c|c|}
\hline \multirow[t]{2}{*}{ Variable } & \multicolumn{3}{|c|}{ Model 1: Good News } & \multicolumn{3}{|c|}{ Model 2: Bad News } \\
\hline & Coefficient & $p$ Value & VIF & Coefficient & $p$ Value & VIF \\
\hline ACSize & -0.039 & 0.362 & 1.51 & 0.158 & $0.011^{* *}$ & 1.51 \\
\hline ACINED & 0.017 & 0.919 & 2.2 & 0.197 & 0.572 & 2.2 \\
\hline ACMeeting & -0.017 & 0.245 & 1.64 & 0.02 & 0.273 & 1.64 \\
\hline ACGender & 0.683 & $0.014^{* *}$ & 2.33 & -0.763 & $0.067 *$ & 2.33 \\
\hline ACNationality & 0.092 & 0.441 & 3.41 & 0.143 & 0.451 & 3.41 \\
\hline ACOverlap & 0.279 & $0.042^{* *}$ & 1.7 & -0.381 & $0.062 *$ & 1.7 \\
\hline ACMul & 0.046 & 0.536 & 1.3 & -0.066 & 0.543 & 1.3 \\
\hline ACFIN & 0 & 0.997 & 1.4 & -0.005 & 0.978 & 1.4 \\
\hline BSize & 0.0535 & $0.021^{* *}$ & 1.97 & -0.059 & $0.074 *$ & 1.97 \\
\hline BINED & -0.108 & 0.442 & 2.39 & 0.15 & 0.565 & 2.39 \\
\hline BMeeting & 0.032 & $0.049 * *$ & 1.66 & -0.025 & 0.258 & 1.66 \\
\hline BGender & -1.134 & $0.019 * *$ & 2.22 & 1.45 & $0.027^{* *}$ & 2.22 \\
\hline BNationality & -0.242 & 0.112 & 3.64 & -0.24 & 0.331 & 3.64 \\
\hline Royal & -0.137 & $0.077 *$ & 1.33 & 0.011 & 0.906 & 1.33 \\
\hline Relatives & -0.076 & 0.222 & 1.46 & -0.147 & 0.218 & 1.46 \\
\hline Big4 & 0.064 & 0.368 & 2.52 & -0.034 & 0.736 & 2.52 \\
\hline Log Total Asset & 0.083 & $0.080 *$ & 2 & 0.009 & 0.862 & 2 \\
\hline LEV & 0.186 & 0.143 & 1.6 & -0.049 & 0.773 & 1.6 \\
\hline \multirow[t]{5}{*}{$\mathrm{ROE}$} & 0.093 & 0.556 & 1.45 & 0.05 & 0.781 & 1.45 \\
\hline & $\mathrm{R}^{2}$ & 0.4444 & & $\mathrm{R}^{2}$ & 0.219 & \\
\hline & Adjusted $\mathrm{R}^{2}$ & 0.23714 & & Adjusted $\mathrm{R}^{2}$ & 0.34007 & \\
\hline & F value & 9.77 & & F value & 1.7 & \\
\hline & Observation & 94 & & Observation & 94 & \\
\hline
\end{tabular}

***, and ${ }^{* * *}$ indicate significance at the $10 \%, 5 \%$, and $1 \%$ levels, respectively. 


\subsubsection{AC Size}

Table 2 shows that ACSize positively affects the disclosure of bad news information related to COVID-19, but it does not affect the disclosure of good news information related to COVID-19. We, therefore, partially accept Hypothesis 1 . This suggests that the size of the $\mathrm{AC}$ is a contributing variable in explaining bad news information related to COVID-19. This conclusion is consistent with resource-dependence theory and with the disclosure literature (Ho and Wong 2001; Bedard and Johnstone 2004; Raimo et al. 2020). Members of large ACs are able to exchange knowledge and skills and this could lead to better disclosure (Allegrini and Greco 2013). The findings also suggest that, in Oman, large ACs enhance directors' monitoring roles.

\subsubsection{AC Independence}

Table 2 shows that ACINED is not a significant variable affecting COVID-related disclosure tone and, therefore, Hypothesis 2 is rejected. This finding is not consistent with agency theory, which suggests that the independence of AC directors could positively affect disclosure levels. One possible explanation for this finding is offered by Ajinkya et al. (2005). They argued that " ... outside directors may be ineffective, either because they are appointed by, or have allegiance to, company managers or because the board culture discourages conflict (Mace (1986), Jensen (1993)). The effectiveness of outside directors and the extent to which they represent shareholder interests could also be influenced by the fear of litigation and reputation costs". (p. 349). Our finding raises an important question that requires further investigation: are independent AC directors really independent? Our finding suggests that more regulatory efforts are needed to understand the bright and dark sides of the independence of AC directors.

\subsubsection{AC Meeting Frequency}

Table 2 also shows that the frequency of AC meetings (ACMeeting) is not a significant variable affecting COVID-related disclosure tone and, therefore, Hypothesis 3 is rejected. This is not consistent with agency theory, which suggests that the number of annual AC meetings affects disclosure levels. This finding, however, is consistent with those of Lin et al. (2006) and Lin and Hwang (2010), who found a negative relationship between disclosure and the frequency of AC meetings. According to Baatwah et al. (2015), AC directors in Oman may be overburdened by the obligation to resolve director disagreements during meetings, such as solving crisis transaction issues, and so devote less time to disclosing such issues. This is in line with the argument by Vitolla et al. (2020) that the decision to adopt a new type of report (information) may not require continuous monitoring (exercised through a high number of annual meetings) but, inversely, could be the result of only a few meetings.

\subsubsection{AC Gender Diversity}

The results shown in Table 2 verify Hypothesis 4 . ACGender shows significant relationships with COVID-related disclosure tone. The coefficient is positive and statistically significant at the $5 \%$ level for good news information, while it was found to be negative and statistically significant at the $10 \%$ level for bad news information. This finding is consistent with agency theory and with previous studies (Albitar et al. 2021; Aribi et al. 2018; Bilimoria and Wheeler 2000). It also provides support to the argument put forth by Gul et al. (2011) that gender diversity improves the board's and its subcommittees' capacity to oversee a firm's disclosures and reports, as well as the dissemination of information. Accordingly, we conclude that gender diversity in the ACs of Omani firms enhances the efficiency of AC monitoring and the COVID-19-related disclosure tone.

\subsubsection{AC Nationality Diversity}

Table 2 also shows that the presence of foreign directors in ACs (ACNationality) does not affect COVID-19-related disclosure tone. Hence, we reject Hypothesis 5. This is 
not a surprising finding. In the current COVID-19 pandemic, travel delays, lockdowns, travel cancellations, quarantines, and the banning of travel from high-risk areas might restrict direct and face-to-face communication between foreign AC directors and other AC directors. Therefore, foreign AC directors could have less time to oversee the financial reporting process and hence to contribute to the COVID-19-related disclosure practice. Al-Matari et al. (2014) also argue that foreign directors require a higher level of compensation and do not focus on the disclosure practice because of their limited knowledge of the national context. Our finding is consistent with Firoozi et al. (2016)'s study, which provides evidence that foreign AC directors play less of a monitoring role and negatively affect voluntary disclosure levels.

\subsubsection{Overlapping AC Members}

Table 2 shows that the estimated coefficient of overlapping members (ACOverlap) is positive and statistically significant with respect to the disclosure of good COVID-19related news at a significance level of $5 \%$ (coefficient $=0.279$ and $p$ value $=0.042$ ), which is consistent with agency theory. Furthermore, our analysis reveals that with respect to the disclosure of bad COVID-19-related news, the impact of overlapping members is negative and statistically significant at the $1 \%$ level (coefficient $=-0.381$ and $p$-value $=0.062$ ). Based on these findings, Hypothesis 6 is accepted. These findings are consistent with agency theory. The findings are also in line with studies on disclosure that find that when directors overlapped, the quality of financial reporting improved (e.g., Al Lawati and Hussainey 2021; Chandar et al. 2012; Habib and Bhuiyan 2016). Theoretically, according to agency theory, these results indicate that having AC members who serve on multiple committees and gain knowledge from across the firm will significantly enhance the monitoring function of these members, leading to an improvement in the disclosure practice. The results offer evidence that overlapping members tend to disclose more good news than bad news (Al Lawati and Hussainey 2021).

\subsubsection{AC Multiple Directorships}

Table 2 shows that AC directors with multiple directorships (ACMul) do not affect the COVID-19-related disclosure tone. Hence, we reject Hypothesis 7. The result suggests that these AC members are busy with other commitments and have no impact on disclosure levels (Mooneeapen et al. 2021). The results are consistent with Fich and Shivdasani (2006) and Liu and Sun (2010), who found that directors who held too many directorships did not have enough time and were too busy to monitor management, and this negatively affected their monitoring roles. Hence, we can conclude that overlapping directors in Omani listed firms are not very beneficial to companies in terms of voluntary disclosures.

\subsubsection{AC Financial Expertise}

Our analysis shows that ACFIN has no impact on the disclosure of good COVID-19related news (coefficient $=0.000$ and $p$ value $=0.997$ ) and the disclosure of bad COVID-19related news (coefficient $=-0.005$ and $p$ value $=0.978$ ). Hence, we reject Hypothesis 8 . The results also do not support the view of Mangena and Pike (2005), who argue that ACs with financial expertise improve disclosure levels. However, the results are consistent with a recent study by Al Lawati et al. (2021) and the studies of Wang and Hussainey (2013) and Raimo et al. (2020), who found that the financial expertise of audit members does not drive voluntary disclosure. Al Lawati et al. (2021, p. 575) provide a possible explanation for this finding: "This could be explained by the possibility that these crucial directors prevent managers from disclosing verifiable information to avoid the risk of high legitimacy and public pressure costs (Ajinkya et al. 2005). Further Bruynseels and Cardinaels (2014) suggest that this could be attributed to the connectedness of AC financial experts to the CEOs, which has an adverse effect on oversight quality, which is consistent with the negative side of the social capital theory. Moreover, because the Omani ACs are mostly made up of 
non-accounting financial experts, this might reduce the power of AC financial experts to influence [disclosure]".

\subsubsection{Control Variables}

The first set of control variables is related to the quality of the board of directors. We found that board size (BSize) is positively associated with the disclosure of good news related to the COVID-19 pandemic at the 5\% significance level, while it is negatively associated with the disclosure of bad news related to the COVID-19 pandemic at the $10 \%$ significance level. Board independence (BINED) has no impact on the disclosure of good COVID-19-related news and bad COVID-19-related news. We also found that the frequency of board meetings (BMeeting) positively influences the disclosure of good COVID-19-related news at a significance level of 5\%. We found that board gender diversity (BGender) is negatively associated with the disclosure of good COVID-19-related news at the $5 \%$ significance level and positively associated with the disclosure of bad COVID-19related news at the $5 \%$ significance level. We found that there is an insignificant association between board nationality diversity (BNationality) and both the disclosure of good COVID19-related news and the disclosure of bad COVID-19-related news. We also found that ruling family directors (Royal) impede the disclosure of good news related to COVID-19. With regard to bad news, royal family members had no impact. Our last observation is related to directors from the same family on the board (Relatives). Our analysis shows that relatives on boards do not contribute to the COVID-related disclosure tone.

The second set of control variables is related to firm characteristics. Consistent with Al Lawati and Hussainey (2021), our analysis shows that the presence of Big Four audit firms (Big4) has no association with the disclosure of good news and bad news related to COVID-19. This finding is also consistent with Albitar et al. (2021), who argued that the quality of external auditing during the COVID-19 pandemic will be reduced and that this could limit its impact on corporate disclosure practices. In line with the study conducted by Elgammal et al. (2018), company size (natural log of total assets) was shown to be positive and significant at the $10 \%$ significance level in relation to the disclosure of good COVID-19-related news, suggesting that large companies disclosed more good news during the pandemic. Leverage (LEV) and Return on Equity (ROE) were not found to have any significant association with both the disclosure of good news and the disclosure of bad news related to COVID-19.

\subsubsection{Discussion}

Table 3 summarizes our key findings. It shows that three AC characteristics affect the COVID-19-related disclosure tone in Oman. These are AC size, gender diversity, and the overlapping of AC members.

Table 3. Summary of the acceptance/rejection of the research hypotheses.

\begin{tabular}{|c|c|c|}
\hline Hypotheses & Supported & Rejected \\
\hline (H1). COVID-19-related disclosure tone is likely to be influenced by AC size. & $\checkmark$ for bad news only & \\
\hline (H2). COVID-19-related disclosure tone is likely to be influenced by AC independence. & & $\boldsymbol{\nu}$ \\
\hline (H3). COVID-19-related disclosure tone is likely to be influenced by AC meetings. & & $\checkmark$ \\
\hline (H4). COVID-19-related disclosure tone is likely to be influenced by AC gender diversity. & $\checkmark$ & \\
\hline (H5). COVID-19-related disclosure tone is likely to be influenced by AC nationality diversity. & & $\boldsymbol{\nu}$ \\
\hline (H6). COVID-19-related disclosure tone is likely to be influenced by AC overlap. & $\checkmark$ & \\
\hline (H7). COVID-19-related disclosure tone is likely to be influenced by AC multiple directorships. & & $\checkmark$ \\
\hline (H8). COVID-19-related disclosure tone is likely to be influenced by AC financial expertise. & & $\checkmark$ \\
\hline
\end{tabular}

Our findings indicate that a large AC size is associated with the reporting of bad news related to COVID-19. Although recent research has shown that board size has not 
mattered during the COVID-19 crisis (Khatib and Nour 2021), our analysis shows that AC size matters to the disclosure of bad COVID-19-related news in Oman. The analysis shows that companies with a large number of AC directors disclosed an increased amount of bad news during the crisis. Further analysis is needed to explore the potential reasons for this phenomenon. Our interpretation here is that Omani companies reported more bad news because their performance declined during the crisis. This is consistent with the recent research findings of Elmarzouky et al. (2021) and might also indicate that Omani companies provided more truthful information in their annual reports during the COVID-19 crisis.

We also found that AC gender diversity positively affects the disclosure of good COVID-19-related news and negatively affects the disclosure of bad COVID-19-related news. It would be interesting to investigate the potential reasons for these findings. Relevant GCC studies (e.g., Al Lawati et al. 2021; Al-Maghzom et al. 2016; Al-Yahyaee et al. 2017) provide evidence that the existence of women on ACs is positively related to voluntary disclosure. Our findings indicate that the existence of women on ACs adds value (e.g., improves levels of disclosure), and regulators should consider this finding when revising the corporate governance code.

Not surprisingly, overlapping AC members have a positive impact on the disclosure of good COVID-19-related news and bad COVID-19-related news. Our findings are in line with recent studies by Al Lawati and Hussainey (2021) and Al Lawati et al. (2021). The Omani corporate governance code allows AC members to overlap with other committees within the same company. The code, however, does not allow the chair of the AC to be overlapped. Our findings suggest that overlapping is beneficial to companies and their stakeholders as it leads to an improvement in the levels of voluntary disclosure. So, regulators might consider allowing the $\mathrm{AC}^{\prime}$ s chair to be overlapped within other committees in a firm, so that more information will be released in annual reports and this will reduce information asymmetry and agency costs.

\section{Conclusions}

This study examined the impact of AC characteristics on the COVID-19-related disclosure tone in Omani listed firms. The study analyzed 95 chairman's statements to identify the disclosure of good and bad news related to the COVID-19 pandemic for the year ended 2020. The study employed a wide range of AC characteristics (size, independence, number of meetings, gender diversity, nationality diversity, committee overlap, multi-directorship and financial expertise) and also controlled for board characteristics and firm-specific characteristics. We found that AC gender diversity and overlapping AC members are positively associated with the disclosure of good news related to COVID-19. The study also documented a positive association between AC size and the disclosure of bad news related to COVID-19, and a negative association with AC gender diversity and AC overlap. Our findings have important implications for corporate governance regulators charged with the setting of disclosure policies. The study shows that ACs were central in determining the quality of voluntary disclosures during the COVID-19 pandemic. The results of the study may be useful for reviewing corporate governance codes across the globe, especially those guidelines related to voluntary disclosure.

There are still some limitations to this study. First, the study focused on Omani listed firms, which may limit the generalizability of our findings as corporate governance practices may be affected by other institutional settings, such as culture, ownership pattern, and legal system. Second, due to the lack of data on ownership, which is believed to impact the governance practices, we could not include the ownership structure in our regression model.

Our paper offers opportunities for future research. First, an opportunity exists to examine the impact of AC characteristics on voluntary disclosure in different institutional settings (Grosvold and Brammer 2011; Aguilera and Crespi-Cladera 2012; Kim and Ozdemir 2014). Second, research is required to examine the readability of the COVID-19related disclosure tone. Third, further research could examine the economic consequences 
of COVID-19-related disclosure tone (e.g., its impact on firm performance, share price, anticipation of earnings, cost of capital, trade credit, investment efficiency, and credit ratings). Fourth, Alkaraan et al. (2021) provide evidence that the transformation toward Industry 4.0 has a positive impact on corporate financial performance. As Industry 4.0 technology became an essential part of how companies survived the COVID-19 pandemic, further research could explore the joint impact of the transformation toward Industry 4.0 and COVID-19-related disclosures on current and future corporate performance. Finally, we understand that information must be faithfully presented in annual reports, including good/bad news. It would be interesting to determine whether the COVID-19-related disclosure tone in annual report narratives is credible and whether users would value external assurance over this type of disclosure.

Author Contributions: Conceptualization, B.A. and S.P.; methodology, B.A. and S.P.; software, B.A.; validation, B.A., S.P. and K.H.; formal analysis, B.A. and S.P; investigation, B.A. and S.P; resources, K.H; data curation, B.A., S.P. and K.H.; writing-original draft preparation, B.A. and S.P; writingreview and editing, B.A. and S.P. and K.H; visualization, B.A. and S.P; supervision, B.A and K.H.; project administration, B.A.; funding acquisition, B.A. and S.P. All authors have read and agreed to the published version of the manuscript.

Funding: This research was funded by the Ministry of Higher Education, Research and InnovationSultanate of Oman under the Block Funding Program (Block Funding Agreement No. TRC/BFP/ SHCT/01/2019).

Institutional Review Board Statement: Not applicable.

Informed Consent Statement: Not applicable.

Data Availability Statement: The source of data supporting reported results are shown in Section 3.1. Data was obtained from annual reports from companies' websites which are listed in the Muscat Securities Exchange (MSX) in Oman.

Acknowledgments: The authors would like to acknowledge that the research leading to these results received funding from the Ministry of Higher Education, Research and Innovation-Sultanate of Oman under the Block Funding Program (Block Funding Agreement No. TRC/BFP/SHCT/01/2019). They would also like to extend their gratitude to the management of the University of Technology and Applied Sciences (UTAS) for motivating and supporting them to complete this research endeavor. In addition, they are grateful to their graduate students, Shahad Alrushdi and Omaima Alshkhari, for assisting the research team to manually collect the required data for the study.

Conflicts of Interest: The author declares no conflict of interest.

\section{References}

Abbott, Lawrence J., Susan Parker, and Gary F. Peters. 2004. Audit Committee Characteristics and Restatements. AUDITING: A Journal of Practice \& Theory 23: 69-87. [CrossRef]

Abdou, Hussein A., Nouran N. Ellelly, Ahmed A. Elamer, Khaled Hussainey, and Hassan Yazdifar. 2021. Corporate governance and earnings management nexus: Evidence from the UK and Egypt using neural networks. International Journal of Finance \& Economics 26: 6281-311. [CrossRef]

Aboody, David, and Baruch Lev. 2000. Information asymmetry, R\&D, and insider gains. The Journal of Finance 55: $2747-66$.

Agrawal, Anup, and Sahiba Chadha. 2005. Corporate Governance and Accounting Scandals. The Journal of Law and Economics 48: 371-406. [CrossRef]

Aguilera, Ruth V., and Rafel Crespi-Cladera. 2012. Firm family firms: Current debates of corporate governance in family firms. Journal of Family Business Strategy 3: 66-69. [CrossRef]

Ajinkya, Bipin, Sanjeev Bhojraj, and Partha Sengupta. 2005. The Association between Outside Directors, Institutional Investors and the Properties of Management Earnings Forecasts. Journal of Accounting Research 43: 343-76. [CrossRef]

Al Lawati, Hidaya, and Khaled Hussainey. 2021. Disclosure of forward-looking information: Does audit committee overlapping matter? International Journal of Accounting and Performance Evaluation. in press.

Al Lawati, Hidaya, Khaled Hussainey, and Roza Sagitova. 2021. Disclosure quality vis-à-vis disclosure quantity: Does audit committee matter in Omani financial institutions? Review of Quantitative Finance and Accounting 57: 557-94. [CrossRef]

Allegrini, Marco, and Giulio Greco. 2013. Corporate boards, audit committees and voluntary disclosure: Evidence from Italian listed companies. Journal of Management E Governance 17: 187-216. 
Alazzani, Abdulsamad, Yaseen Aljanadi, and Obeid Shreim. 2019. The impact of existence of royal family directors on corporate social responsibility reporting: A servant leadership perspective. Social Responsibility Journal 15: 120-36. [CrossRef]

Albitar, Khaldoon, Habiba Al-Shaer, and Mahmoud Elmarzouky. 2021. Do assurance and assurance providers enhance COVID-related disclosures in CSR reports? An examination in the UK context. International Journal of Accounting E Information Management 29: 410-28. [CrossRef]

Al-Hadi, Ahmed, Grantley Taylor, and Khamis Hamed Al-Yahyaee. 2016. Ruling Family Political Connections and Risk Reporting: Evidence from the GCC. The International Journal of Accounting 51: 504-24. [CrossRef]

Alkaraan, Fadi, Khaldoon Albitar, Khaled Hussainey, and Vg Venkatesh. 2021. Corporate transformation toward Industry 4.0 and financial performance: The influence of environmental, social, and governance (ESG). Technological Forecasting and Social Change 175: 121423. [CrossRef]

Allini, Alessandra, Francesca Manes Rossi, and Khaled Hussainey. 2016. The board's role in risk disclosure: An exploratory study of Italian listed state-owned enterprises. Public Money \& Management 36: 113-20.

Allini, Alessandra, Francesca Manes Rossi, and Riccardo Macchioni. 2014. Do Corporate Governance Characteristics Affect NonFinancial Risk Disclosure in Government-owned Companies? The Italian Experience. Financial Reporting 1: 5-31. [CrossRef]

Al-Maghzom, Abdullah, Khaled Hussainey, and Doaa Aly. 2016. Corporate governance and risk disclosure: Evidence from Saudi Arabia. Corporate Ownership and Control 13: 145-66. [CrossRef]

Al-Matari, Ebrahim Mohammed, Abdullah Kaid Al-Swidi, and Faudziah Hanim Bt Fadzil. 2014. The Measurements of Firm Performance's Dimensions. Asian Journal of Finance \& Accounting 6: 24. [CrossRef]

Al-Najjar, Basil, and Suzan Abed. 2014. The association between disclosure of forward-looking information and corporate governance mechanisms: Evidence from the UK before the financial crisis period. Managerial Auditing Journal 29: 578-95. [CrossRef]

Al-Shaer, Habiba, Aly Salama, and Steven Toms. 2017. Audit committees and financial reporting quality: Evidence from UK environmental accounting disclosures. Journal of Applied Accounting Research 18: 2-21. [CrossRef]

Al-Shaer, Habiba, and Mahbub Zaman. 2018. Credibility of sustainability reports: The contribution of audit committees. Business Strategy and the Environment 27: 973-86. [CrossRef]

Al-Shaer, Habiba, Khaldoon Albitar, and Khaled Hussainey. 2021. Creating sustainability reports that matter: An investigation of factors behind the narratives. Journal of Applied Accounting Research. ahead-of-print. [CrossRef]

Al-Yahyaee, Khamis Hamed, Ahmed Khamis Al-Hadi, and Syed Mujahid Hussain. 2017. Market Risk Disclosures and Board Gender Diversity in Gulf Cooperation Council (GCC) Firms. International Review of Finance 17: 645-58. [CrossRef]

Appuhami, Ranjith, and Shamim Tashakor. 2017. The Impact of Audit Committee Characteristics on CSR Disclosure: An Analysis of Australian Firms. Australian Accounting Review 27: 400-20. [CrossRef]

Arcay, M. Rosario Babío, and M. Flora Muiño Vázquez. 2005. Corporate Characteristics, Governance Rules and the Extent of Voluntary Disclosure in Spain. Advances in Accounting 21: 299-331. [CrossRef]

Aribi, Zakaria Ali, Rateb Mohammad Alqatamin, and Thankom Arun. 2018. Gender diversity on boards and forward-looking information disclosure: Evidence from Jordan. Journal of Accounting in Emerging Economies 8: 205-22. [CrossRef]

Ayman, Ahmed, Moataz El-Helaly, and Nermeen Shehata. 2019. Board diversity and earnings news dissemination on Twitter in the UK. Journal of Management and Governance 23: 715-34. [CrossRef]

Baatwah, Saeed Rabea, Zalailah Salleh, and Norsiah Ahmad. 2015. Corporate governance mechanisms and audit report timeliness: empirical evidence from Oman. International Journal of Accounting, Auditing and Performance Evaluation 11: 312-37. [CrossRef]

Barako, Dulacha G., Phil Hancock, and H.Y. Izan. 2006. Factors Influencing Voluntary Corporate Disclosure by Kenyan Companies. Corporate Governance: An International Review 14: 107-25. [CrossRef]

Beasley, Mark S. 1996. An empirical analysis of the relation between the board of director composition and financial statement fraud. Accounting Review 1996: 443-65.

Bedard, Jean C., and Karla M. Johnstone. 2004. Earnings manipulation risk, corporate governance risk, and auditors' planning and pricing decisions. The Accounting Review 79: 277-304. [CrossRef]

Bilimoria, Diana, and Jane V. Wheeler. 2000. Women Corporate Directors: Current Research and Future Directions. Women in Management: Current Research Issues 2: 138-63. [CrossRef]

Boshnak, Helmi A. 2021. Determinants of corporate social and environmental voluntary disclosure in Saudi listed firms. Journal of Financial Reporting and Accounting. ahead-of-print. [CrossRef]

Bruynseels, Liesbeth, and Eddy Cardinaels. 2014. The audit committee: Management watchdog or personal friend of the CEO? The Accounting Review 89: 113-45. [CrossRef]

Cao, Jian, Kimberly M. Ellis, and Mingxiang Li. 2019. Inside the board room: The influence of nationality and cultural diversity on cross-border merger and acquisition outcomes. Review of Quantitative Finance and Accounting 53: 1031-68. [CrossRef]

Chandar, Nandini, Hsihui Chang, and Xiaochuan Zheng. 2012. Does overlapping membership on audit and compensation committees improve a firm's financial reporting quality? Review of Accounting and Finance 11: 141-65. [CrossRef]

Chang, Jui-Chin, Mi Luo, and Huey-Lian Sun. 2011. The impact of independent and overlapping board structures on CEO compensation, pay-performance sensitivity and accruals management. Quarterly Journal of Finance E Accounting 50: 54-84.

CMA. 2016. Available online: https://cma.gov.om/documents/en/CMACodeofCorporateGovernance-English-31stMarch2015.pdf (accessed on 1 September 2021).

CMA. 2021. Available online: https:/ / www.cma.gov.om/Home/AboutCMA/VisionNMission (accessed on 1 September 2021). 
Elgammal, Mohammed M., Khaled Hussainey, and Fatma Ahmed. 2018. Corporate governance and voluntary risk and forward-looking disclosures. Journal of Applied Accounting Research 19: 592-607. [CrossRef]

Elmarzouky, Mahmoud, Khaldoon Albitar, and Khaled Hussainey. 2021. COVID-19 and performance disclosure: Does governance matters? International Journal of Accounting and Information Management 29: 776-92. [CrossRef]

Elshandidy, Tamer, Ian Fraser, and Khaled Hussainey. 2013. Aggregated, voluntary, and mandatory risk disclosure incentives: Evidence from UK FTSE all-share companies. International Review of Financial Analysis 30: 320-33. [CrossRef]

Eng, Li Li, and Yuen Teen Mak. 2003. Corporate governance and voluntary disclosure. Journal of Accounting and Public Policy 22: 325-45. [CrossRef]

Eulaiwi, Baban, Ahmed Al-Hadi, Grantley Taylor, Khamis Hamed Al-Yahyaee, and John Evans. 2016. Multiple directorships, family ownership and the board nomination committee: International evidence from the GCC. Emerging Markets Review 28: 61-88. [CrossRef]

Fama, Eugene F., and Michael C. Jensen. 1983. Separation of Ownership and Control. The Journal of Law and Economics 26: 301-25. [CrossRef]

Fich, Eliezer, and Anil Shivdasani. 2006. Are busy boards effective monitors? The Journal of Finance 61: 689-724. [CrossRef]

Firoozi, Maryam, Michel Magnan, and Steve Fortin. 2016. Board Diversity and Financial Reporting Quality. Available online: https:/ /ir.library.carleton.ca/pub/22414/ (accessed on 27 November 2021).

Gebrayel, Elias, Hajer Jarrar, Charbel Salloum, and Quentin Lefebvre. 2018. Effective association between audit committees and the internal audit function and its impact on financial reporting quality: Empirical evidence from Omani listed firms. International Journal of Auditing 22: 197-213. [CrossRef]

Grassa, Rihab, Nejia Moumen, and Khaled Hussainey. 2020. What drives risk disclosure in Islamic and conventional banks? An international comparison. International Journal of Finance $\mathcal{E}$ Economics 26: 6338-61.

Grosvold, Johanne, and Stephen Brammer. 2011. National institutional systems as antecedents of female board representation: An empirical study. Corporate Governance: An International Review 19: 116-35. [CrossRef]

Gul, Ferdinand A., Bin Srinidhi, and Anthony C. Ng. 2011. Does board gender diversity improve the informativeness of stock prices? Journal of Accounting and Economics 51: 314-38. [CrossRef]

Habib, Ahsan, and Md Borhan Uddin Bhuiyan. 2016. Overlapping membership on audit and compensation committees and financial reporting quality. Australian Accounting Review 26: 76-90. [CrossRef]

Haniffa, Roszaini M., and Terry E. Cooke. 2005. The impact of culture and governance on corporate social reporting. Journal of Accounting and Public Policy 24: 391-430. [CrossRef]

Haniffa, Rozaini Mohd, and Terence E. Cooke. 2002. Culture, corporate governance and disclosure in Malaysian corporations. Abacus 38: 317-49. [CrossRef]

Ho, Simon, and Kar Shun Wong. 2001. A study of the relationship between corporate governance structures and the extent of voluntary disclosure. Journal of International Accounting, Auditing and Taxation 10: 139-56. [CrossRef]

Jensen, Michael C. 1993. The modern industrial revolution, exit, and the failure of internal control systems. The Journal of Finance 48: 831-80. [CrossRef]

Jensen, Michael C., and William H. Meckling. 1976. Theory of the firm: Managerial behavior, agency costs and ownership structure. Journal of Financial Economics 3: 305-60. [CrossRef]

Karamanou, Irene, and Nikos Vafeas. 2005. The association between corporate boards, audit committees, and management earnings forecasts: An empirical analysis. Journal of Accounting Research 43: 453-86. [CrossRef]

Karim, Khondkar, Ashok Robin, and SangHyun Suh. 2016. Board structure and audit committee monitoring: Effects of audit committee monitoring incentives and board entrenchment on audit fees. Journal of Accounting, Auditing and Finance 31: 249-76. [CrossRef]

Khaireddine, Hanen, Bassem Salhi, Jabr Aljabr, and Anis Jarboui. 2020. Impact of board characteristics on governance, environmental and ethical disclosure. Society and Business Review 15: 273-95. [CrossRef]

Khatib, Saleh F. A., and Abdul-Naser Ibrahim Nour. 2021. The impact of corporate governance on firm performance during the COVID-19 pandemic: Evidence from Malaysia. Journal of Asian Finance, Economics and Business 8: 943-52.

Kim, Young Un, and Salih Zeki Ozdemir. 2014. Structuring corporate boards for wealth protection and/or wealth creation: The effects of national institutional characteristics. Corporate Governance: An International Review 22: 266-89. [CrossRef]

Krippendorff, Klaus. 2004. Measuring the reliability of qualitative text analysis data. Quality and Quantity 38: 787-800. [CrossRef]

Larmou, Sofia, and Nikos Vafeas. 2010. The relation between board size and firm performance in firms with a history of poor operating performance. Journal of Management E Governance 14: 61-85.

Li, Jing, Musa Mangena, and Richard Pike. 2012. The effect of audit committee characteristics on intellectual capital disclosure. The British Accounting Review 44: 98-110. [CrossRef]

Lin, Jerry, June Li, and Joon Yang. 2006. The effect of audit committee performance on earnings quality. Managerial Auditing Journal 21: 921-33. [CrossRef]

Lin, Jerry, and Mark Hwang. 2010. Audit quality, corporate governance, and earnings management: A meta-analysis. International Journal of Auditing 14: 57-77. [CrossRef]

Liu, Guoping, and Jerry Sun. 2010. Director tenure and independent audit committee effectiveness. International Research Journal of Finance and Economics 51: 176-89.

Mace, Myles La Grange. 1986. Directors, Myth and Reality. No. 4. Boston: Harvard Business Review Press. 
Mangena, Musa, and Richard Pike. 2005. The effect of audit committee shareholding, financial expertise and size on interim financial disclosures. Accounting and Business Research 35: 327-49. [CrossRef]

Mcchlery, Stuart, and Khaled Hussainey. 2021. Risk disclosure behaviour: Evidence from the UK extractive industry. Journal of Applied Accounting Research 22: 484-506. [CrossRef]

Mooneeapen, Oren, Subhash Abhayawansa, Dinesh Ramdhony, and Zainab Atchia. 2021. New insights into the nexus between board characteristics and intellectual capital disclosure: The case of the emerging economy of Mauritius. Journal of Accounting in Emerging Economies. ahead-of-print. [CrossRef]

Nicolo, Giuseppe, Giuseppe Sannino, and Serena De Iorio. 2021. Gender diversity and online intellectual capital disclosure: Evidence from Italian-listed firms. Journal of Public Affairs. [CrossRef]

Nindiasari, Avininda Dewi. 2021. Good corporate governance practices and voluntary disclosure in companies listed in the Indonesia Sharia Stock Index (ISSI). Asian Journal of Islamic Management 3: 45-55. [CrossRef]

Raimo, Nicola, Filippo Vitolla, Arcangelo Marrone, and Michele Rubino. 2020. The role of ownership structure in integrated reporting policies. Business Strategy and the Environment 29: 2238-50. [CrossRef]

Raimo, Nicola, Filippo Vitolla, Arcangelo Marrone, and Michele Rubino. 2021. Do audit committee attributes influence integrated reporting quality? An agency theory viewpoint. Business Strategy and the Environment 30: 522-34. [CrossRef]

Ross, Stephen A. 1973. The economic theory of agency: The principal's problem. The American Economic Review 63: 134-39.

Saha, Rupjyoti, and Kailash Chandra Kabra. 2021. Corporate governance and voluntary disclosure: Evidence from India. Journal of Financial Reporting and Accounting. ahead-of-print. [CrossRef]

Salem, Issal Haj, and Khaled Hussainey. 2021. A content analysis of narrative COVID-19 disclosure in Omani Islamic banks. In Corporate Narrative Reporting: Beyond the Numbers. Edited by Mahmoud Marzouk and Khaled Hussainey. London: Routledge.

Sharma, Vineeta D., and Errol R. Iselin. 2012. The association between audit committee multiple-directorships, tenure, and financial misstatements. Auditing: A Journal of Practice E Theory 31: 149-75.

Shehadeh, Esam, Doaa Aly, and Ibrahim Yousef. 2021. The impact of boardroom internationalisation on online disclosures of S\&P 500. Journal of Financial Reporting and Accounting 19: 596-614. [CrossRef]

Shivdasani, Anil, and David Yermack. 1999. CEO involvement in the selection of new board members: An empirical analysis. The Journal of Finance 54: 1829-53. [CrossRef]

Smith, Matthew, and Yasaman Sarabi. 2021. What do interlocks do" revisited-a bibliometric analysis. Management Research Review 44: 642-59. [CrossRef]

Smith, Robert. 2003. Audit Committees Combined Code Guidance. London: Financial Reporting Council.

Sultana, Nigar, Harjinder Singh, and Asheq Rahman. 2019. Experience of audit committee members and audit quality. European Accounting Review 28: 947-75. [CrossRef]

Velte, Patrick. 2021. Effect of Overlapping Audit and Compensation Committee Memberships on the Readability of Management Compensation Reports in the German HDAX. Journal of Managerial Issues 33: 27-48.

Vitolla, Filippo, Nicola Raimo, and Michele Rubino. 2020. Board characteristics and integrated reporting quality: An agency theory perspective. Corporate Social Responsibility and Environmental Management 27: 1152-63. [CrossRef]

Wang, Mingzhu, and Khaled Hussainey. 2013. Voluntary forward-looking statements driven by corporate governance and their value relevance. Journal of Accounting and Public Policy 32: 26-49. [CrossRef]

XBRL. 2020. Available online: https:/ / www.xbrl.org/news/oman-announces-xbrl-disclosures-platform (accessed on 1 September 2021).

Xie, Biao, Wallace N. Davidson III, and Peter J. DaDalt. 2003. Earnings management and corporate governance: The role of the board and the audit committee. Journal of Corporate Finance 9: 295-316. [CrossRef]

Zahra, Shaker A., and Igor Filatotchev. 2004. Governance of the entrepreneurial threshold firm: A knowledge-based perspective. Journal of Management Studies 41: 885-97. [CrossRef] 